\title{
PELATIHAN REPARASI DAN PERAWATAN ALAT LISTRIK RUMAH TANGGA UNTUK PEMUDA PESISIR
}

\author{
TRAINING OF REPAIR AND MAINTENANCE OF HOME APPLIANCES \\ FOR YOUTH COASTAL
}

\author{
1) Juli Sardi, , ${ }^{2}$ Ali Basrah Pulungan \\ 1,2 Jurusan Teknik Elektro Fakultas Teknik Universitas Negeri Padang \\ Jl. Prof. Dr. Hamka, Kampus UNP Air Tawar Padang \\ email: julisardi@ft.unp.ac.id
}

\begin{abstract}
ABSTRAK
Kegiatan ini dilatarbelakangi oleh tingginya angka kemiskinan di Kelurahan Air Tawar Barat Kota Padang. Berdasarkan data BPS Kota Padang, jumlah keluarga yang termasuk kategori pra sejahtera dan sejahtera 1 pada tahun 2016 terdata sebanyak 421 keluarga dan umumnya terdapat pada kawasan pesisir pantai. Tujuan dari kegiatan ini adalah meningkatkan keterampilan dan keahlian dalam bidang reparasi dan perawatan alat listrik rumah tangga dengan kelompok sasaran para pemuda pesisir pantai. kegiatan dilakukan selama tiga hari dengan jumlah peserta sebanyak 12 orang. Metode yang digunakan adalah pelatihan yang disertai dengan ceramah, demonstrasi, praktek dan evaluasi. Ada 2 jenis evaluasi yang dilakukan yaitu pre test dan post test. Pre test dilaksanakan sebelum kegiatan pelatihan dimulai. Post test dilakukan setelah semua kegiatan pelatihan selesai dilaksanakan. Hasil dari pelatihan menunjukan nilai sig. (2-Tailed) pre test ke post test sebesar 0,016 dengan taraf signifikansi 0,001 (p<0,05). Hal ini menunukan bahwa ada pengaruh yang signifikan pelatihan terhadap peningkatan keterampilan peserta dalam bidang reparasi dan perawatan alat listrik rumah tangga seperti Setrika Listrik, Rice Cooker, Blender, Mixer dan Kipas Angin.
\end{abstract}

Kata kunci : Pelatihan, Reparasi, Alat Listrik Rumah Tangga

\section{ABSTRACT}

The background of Activities is the high poverty in Village Air Tawar Barat, Padang City. Based on BPS data of Padang City, the number of families belonging to the prosperous and prosperous category 1 was recorded as many as 421 families and generally found in the coastal areas. The objectives of this activity is to improve the skills and expertise in the field of repair and maintenance of household electrical appliances with target groups of coastal youth. The training was conducted for three days with a total of 12 participants. The method used is lecture, demonstration, practice and evaluation. There are 2 types of evaluation that is pre test and post test. Pre test is implemented before the training begins. Post test is done after all training activities are carried out. The results of the training show the sig value. (2-Tailed) pre test to post test is 0.016 with a significance level of 0.001 ( $p<0.05)$. This indicates that there is a significant influence of training on improving the skills of participants in the field of repairs and maintenance of household electrical appliances such as Electric Iron, Rice Cookers, Blenders, Mixers and Fans.

Keywords: Training, Repairs, Home Appliances

\section{PENDAHULUAN}

Kelurahan Air Tawar Barat merupakan salah satu kelurahan yang terletak di Kecamatan Padang Utara Kota Padang. Dari Renstra Kecamatan Padang
Utara 2014-2019 diketahui Jumlah penduduk di Kelurahan Air Tawar Barat adalah 15.748 jiwa dan merupakan yang terbesar jika dibandingkan dengan jumlah penduduk kelurahan lain yang ada di 
Kecamatan Padang Utara. Secara umum, dilihat dari infrastruktur, sarana dan prasarana yang ada sudah bagus dan lengkap. Jalan-jalan umumnya sudah diaspal dan kualitasnya cukup baik.

Fasilitas kesehatan yang terdapat di Kelurahan Air tawar Barat berjumlah 15 unit, yang terdiri dari 1 unit Puskesmas, 1 unit Puskesmas Pembantu dan 13 unit Posyandu. Sementara itu, fasilitas pendidikan berupa sekolah baik negeri maupun swasta juga tersedia lengkap di Kelurahan Air tawar Barat yang terdiri dari 8 TK, 7 SD, 2 SMA dan 1 PT.

Jumlah keluarga yang termasuk kategori pra sejahtera dan sejahtera 1 masih tinggi yaitu sebesar 421 keluarga. Untuk itu perlu berbagai upaya untuk meningkatkan pendapatan dan kualitas hidup masyarakat yang ada di Kelurahan Air Tawar Barat. Kawasan yang paling banyak terdapat masyarakat miskin di Kelurahan Air Tawar Barat berada di sepanjang pesisir pantai yang terdapat pada kelurahan tersebut. Umumnya mereka berprofesi sebagai nelayan dan disana juga banyak terdapat anak putus sekolah, selain itu banyak juga ditemukan pemuda usia produktif yang tidak bekerja (pengangguran).

Permasalahan yang ada di Kelurahan Air Tawar Barat adalah masih besarnya jumlah keluarga pra sejahtera dan sejahtera 1. Selain itu angka pengangguran dan anak putus sekolah cukup tinggi. Oleh karena itu, perlu dilakukan berbagai upya untuk membantu mengatasi berbagai permasalahan tersebut. Salah satu upaya yang bisa dilakukan adalah dengan memberikan berbagai keterampilan sebagai bekal untuk meningkatkan kualitas hidup dan penghasilan masyarakat.

Berdasarkan analisis situasi dan permasalahan yang diperoleh dari hasil survey maka diperlukan keterampilan tambahan berupa pelatihan reparasi dan perawatan alat listrik rumah tangga untuk para pemuda di pesisir pantai Kelurahan
Air tawar Barat. Tujuannya adalah untuk memberikan keterampilan dan keahlian dalam bidang reparasi dan perawatan alat listrik rumah tangga sehingga bisa membantu mereka dalam pengembangan kemandirian dan kewirausahaan serta menumbuhkan rasa percaya diri dalam menghadapi masa depan.

\section{METODE}

Metode yang digunakan berupa pelatihan yang bertujuan untuk menghasilkan keterampilan dalam bidang reparasi dan perawatan alat listrik rumah tangga. Untuk melihat tingkat keberhasilan pelatihan dianalisis dengan teknik Paired Sample T-Test yaitu untuk melihat ada tidaknya perbedaan gain score antara pretest dan post-test pada peserta pelatihan yang berjumlah 12 orang.

Kegiatan dimulai dengan mengidentifikasi tingkat pengetahuan peserta tentang reparasi dan perawatan alat listrik rumah tangga dengan cara melakukan pretest tertulis. Jumlah soal yang diujikan berjumlah 15 soal.

Setelah pretest dilakukan, selanjutnya diberikan pelatihan kepada peserta. Materi pelatihan meliputi Kesehatan dan Keselamatan Kerja (K3) dan memperbaiki berbagai jenis kerusakan yang terjadi pada setrika listrik, mixer, kipas angin dan penanak nasi. Di sini akan dikenalkan berbagai komponen yang terdapat pada peralatan-peralatan listrik rumah tangga, bagaimana cara membongkar peralatan tersebut dengan aman, mendiagnosis berbagai kerusakan dan memasang kembali setelah peralatan tersebut selesai diperbaiki.

\section{HASIL DAN PEMBAHASAN}

Hasil uji t (t-test) pre test ke post test menunjukkan nilai Sig. (2-Tailed) $=0,016$ 
dengan taraf signifikansi $0,001 \quad(\mathrm{p}<0,05)$. Skor rerata pre test 61,15 menjadi skor rerata post test 117,82 . Setelah dilakukan perhitungan pada peserta pelatihan diperoleh hasil bahwa secara statistik terjadi perubahan yang signifikan pada pengetahuan dan keterampilan dalam mereparasi dan memperbaiki berbagai peralatan rumah tangga setelah diberikan perlakuan berupa pelatihan. Hasil analisis data menunjukkan tingkat keterampilan peserta meningkat signifikan. Peningkatan keterampilan yang terjadi pada peserta dapat dikatakan sesuai dengan teori experiental learning yang menyatakan bahwa metode pelatihan merupakan metode yang efektif meningkatkan pengetahuan dan keterampilan (Hariandja, 2002).

Pelatihan merupakan sebuah proses mengajarkan pengetahuan dan keahlian tertentu serta sikap agar semakin terampil dan mampu melaksanakan tanggung jawabnya dengan semakin baik, sesuai dengan standar. (Mangkuprawira, 2004) mengatakan pelatihan juga merupakan metode yang efektif untuk mengubah struktur kognitif, memodifikasi sikap dan mengubah keterampilan karena melibatkan proses belajar yang efektif.

$\begin{array}{lrr}\text { Semakin peserta } & \text { pelatihan } \\ \text { berpartisipasi aktif dalam } & \text { kegiatan } \\ \text { pelatihan maka semakin } & \text { banyak }\end{array}$ pengetahuan yang dimiliki karena semakin banyak informasi yang diperoleh dan peserta pelatihan dapat menerapkan secara langsung dalam kegiatan kerja sehari-hari. Peningkatan keterampilan peserta setelah dilakukan intervensi berupa pelaksanaan pelatihan masih dalam tataran kognitif, dimana peserta baru saja memperoleh pengetahuan baru mengenai berbagai cara yang bisa dilakukan untuk mengidentifikasi jenis kerusakan serta memperbaiki berbagai peralatan listrik rumah tangga. Selain ilmu yang diperoleh masih dalam tataran kognitif, peserta juga masih belum merasakan pengalaman berlatih pada suasana pekerjaan yang sesungguhnya. Idealnya, perkembangan skills dari pelatihan harus melewati tiga fase yaitu fase kognitif, fase asosiatif, dan fase autonomi (Randall, 2010).

Fase kognitif merupakan fase memperoleh pengetahuan intelektual mengenai ketrampilan yang dipelajari. Fase asosiatif adalah fase saat peserta training kembali pada dunia kerja dan mencoba mempraktekkan perilaku baru sesuai dengan yang ia pelajari selama pelatihan. Sedangkan fase autonomi adalah fase dimana perilaku telah muncul secara otomatis akibat proses pembiasaan. Pada penelitian ini, partisipan baru sampai pada fase kognitif, sehingga mereka belum merasakan mamfaat secara langsung.

Pelatihan yang telah dilaksanakan menggunakan metode experiential learning, yang artinya melibatkan peserta secara aktif di setiap sesi pelatihan sehingga peserta belajar dan mengalami secara langsung setiap proses selama pelatihan. Hal tersebut dilakukan dengan cara melakukan ceramah dan tanya jawab antara peserta dan trainer, melakukan demonstrasi dan peserta disuruh melakukan praktek langsung terhadap berbagai peralatan listrik rumah tangga. Keberhasilan pelatihan ini dipengaruhi oleh banyak hal, antara lain kompetensi trainer dalam memberikan materi, kelengkapan sarana dan peralatan untuk melakukan praktek, antusiasme peserta saat mengikuti pelatihan, hal ini diketahui dari hasil observasi selama pelatihan berlangsung.

Peserta pelatihan terlihat aktif dalam memberikan argumen terhadap materi pelatihan melalui pertanyaan-pertanyaan. Selain itu, peserta juga aktif terlibat dalam praktek dan diskusi yang diadakan. Peserta juga memberikan penilaian terhadap proses pelatihan yang berlangsung pada akhir proses pelatihan. Evaluasi pelatihan yang terdiri dari evaluasi terhadap materi 
Juli Sardi, Ali Basrah Pulungan

Pelatihan Reparasi Dan Perawatan Alat Listrik Rumah Tangga Untuk Pemuda Pesisir

pelatihan, trainer atau pelatih. menurut peserta pelatihan, materi yang diberikan sesuai dengan kebutuhan untuk meningkatkan keterampilan yang diperlukan dalam memperbaiki berbagai peralatan listrik rumah tangga.

Tanggapan mengenai pemateri pelatihan, peserta pelatihan merasa puas dan senang dengan cara yang digunakan pelatih dalam menyampaikan materi pelatihan sehingga peserta bisa menyerap dan memahami infromasi yang disampaikan. Begitu juga dengan proses pelatihan, secara keseluruhan peserta merasa puas dengan proses pelatihan yang berlangsung.

\section{SIMPULAN}

Pelatihan reparasi dan perawatan alat listrik rumah tangga yang dilaksankan mampu meningkatkan pengetahuan dan keterampilan peserta. Keterampilan yang didapatkan oleh peserta diharapkan mampu dimamfaatkan dalam kehidupan seharihari. Kedepannya diperlukan pelatihan kewirausahaan bagi peserta sehingga keterampilan yang sudah didapatkan mampu dipergunakan dalam berwirausaha.

\section{DAFTAR PUSTAKA}

Hariandja. (2002). Manajemen Sumber Daya Manusia: Pengadaan, Pengembangan, Pengkompensasian dan Peningkatan Produktivitas Pegawai. Jakarta: Grasindo Widiasarana Indonesia.

Mangkuprawira, S. (2004). Manajemen Sumber Daya Manusia Strategik. Jakarta Selatan: Ghalia Indonesia.

Randal, R. \& Arnold, J. (2010). Work Psychology: Understanding Human Behavior in the Workplace. London: Pearson Education Limited.
Badan Pusat Statistik (BPS) Kota Padang. (2016). Kecamatan Padang Utara Dalam Angka 2016.

Peraturan Menteri Pendidikan dan Kebudayaan Republik Indonesia, Nomor 49 Tahun 2014 Tentang Standar Nasional Pendidikan Tinggi. 